https://doi.org/10.15407/ujpe65.6.533

H. AHMED ${ }^{1}$ A. HASHIM, ${ }^{1}$ H.M. ABDULJALIL ${ }^{2}$

${ }^{1}$ University of Babylon, College of Education for Pure Sciences, Department of Physics

(Iraq; e-mail: ahmed_taay@yahoo.com)

${ }^{2}$ University of Babylon, College of Science, Department of Physics

(Iraq; e-mail: ahmed_taay@yahoo.com)

\title{
DETERMINATION OF OPTICAL
}

PARAMETERS OF FILMS OF PVA $/ \mathrm{TiO}_{2} / \mathrm{SiC}$ AND PVA $/ \mathrm{MgO} / \mathrm{SiC}$ NANOCOMPOSITES

FOR OPTOELECTRONICS AND UV-DETECTORS

\begin{abstract}
The optical properties of polyvinyl alcohol (PVA)-titanium oxide $\left(\mathrm{TiO}_{2}\right)$-silicon carbide ( $\left.\mathrm{SiC}\right)$ and (PVA)-magnesium oxide (MgO)-(SiC) nanocomposites are calculated, by using the Gaussian 09 and Gaussian view 5.0 .8 programs on the basis of the density functional theory at B3LYP level with 6-31 $G$ basis set. The results indicate that the absorbance, absorption coefficient, extinction coefficient, refractive index, imaginary and real dielectric constants, and optical conductivity of $\left(\mathrm{PVA}-\mathrm{TiO}_{2}-\mathrm{SiC}\right)$ and $(\mathrm{PVA}-\mathrm{MgO}-\mathrm{SiC})$ increase with the concentration of SiC nanoparticles. Both nanocomposites have high absorbance in the $U V$ region and have indirect energy gaps $1 \mathrm{eV}<E_{g}<2.2 \mathrm{eV}$. This makes them useful for various applications in optoelectronics, photovoltaics, lasers, solar cells, sensors, photocatalytic devices, light filters, UV detectors, etc. with low cost, easy fabrication, and adaptability as compared with other devices.

Keywords: optical properties, nanocomposites, DFT, optoelectronics, UV-detectors.
\end{abstract}

\section{Introduction}

Nanotechnology plays a very important role in modern researches in the treatments of infection, cancer, allergy, diabetes, and inflammation. In green chemistry, it is used to minimize the use of products hazardous to the environment [1]. It has applications in technology and science to manipulate the matter on the atomic and molecular scales and gives the aptitude to build micro- and macromaterials and products with atomic accuracy [2]. Nanotechnology is not novel to polymer science, but nanoscale dimensions were not specifically mentioned as nanotechnology till lately [3]. In a polymer nanocomposite, its polymer

(c) H. AHMED, A. HASHIM, H.M. ABDULJALIL, 2020

ISSN 2071-0194. Ukr. J. Phys. 2020. Vol. 65, No. 6 contains an armored nanoscale matrix (nanoparticle) like nanoparticles, nanotubes, etc. Physical properties of nanocomposites depend largely on the interaction between polymer molecules and nanofillers [4]. The polymer nanocomposites greatly rely on the aggregation, size distribution, geometry, and surface chemistry of organic and inorganic nanoparticles in addition to the matrix-nanoparticle bonds [5]. Emerging nanocomposites could be a solution to regulate the properties of separate nanomaterials suitably. In the field of semiconductor materials, nanocomposites consisting of two or more materials are widely used to change their electronic and optical properties [6]. Transition metal oxides are well identified for their large variety of chemical and physi- 
cal properties. Numerous of these materials undergo phase transitions, which stimulate structural, magnetic, and electronic behavior [7]. Introducing metal oxides like $\mathrm{SnO}_{2}, \mathrm{ZnO}, \mathrm{TiO}_{2}$ and others semiconductors into organic matrices offers higher physical and chemical stabilities [8]. Poly (vinyl alcohol) is a non-toxic biocompatible synthetic polymer with high dielectric strength, good transparency, and intense charge transfer at the electrode-nanocomposite interface [9]. It has the carbon chain backbone with hydroxyl groups $(-\mathrm{OH})$ linked with methane carbons. These $(-\mathrm{OH})$ groups can be a source of hydrogen bonds and participate in the formation of inorganic nanoparticles inside the PVA material [10]. One of the most desirable materials widely used in applications owing its optical and electronic properties is titanium dioxide $\left(\mathrm{TiO}_{2}\right)$ [11]. The FTIR spectra of wholly films showed the presence of $\mathrm{Ti}-\mathrm{O}-\mathrm{C}$ bonds showing a good compatibility of the polymer matrix and $\mathrm{TiO}_{2}$ nanoparticles [12]. Nanoparticles with a metal oxide like $\mathrm{MgO}, \mathrm{ZnO}$, and $\mathrm{CaO}$ were inspected as inorganic antibacterial agents. $\mathrm{MgO}$ is an example of important inorganic material having a wide band gap $(7.8 \mathrm{eV})$ and was used in various applications including, catalysts supports, heat resistant adsorbents, and so on. In medicine, $\mathrm{MgO}$ is used to cure heart diseases and to facilitate bone regeneration. Recently, MgO nanoparticles have shown a promising application in the treatment of tumors. Nanomaterials promise a great development of applications in the aerospace sector due to its low density, high strength, and heat resistance $[13,14]$. In what follows, we will use ones of the famous programs in computational chemistry such as the Gaussian 09 and Gaussian view 5.0.8. It is worth to mention that the first distributed Gaussian package was labeled Gaussian 70 [15].

\section{Theoretical Part}

The optical properties of a nanomaterial are based on parameters such as the shape, surface characteristics, feature size, and other variables including the doping and interaction with the surrounding environment or other nanostructures [15]. Polymers with nanoparticles including oxides of metals are studied, in particular, as materials for optical applications such as planar waveguide devices and microoptical elements. The growth of of used polymer nanocomposite structures is caused by their advantages in production and processing, good connection with strength- ening elements, resistant to the environmental corrosion, light weight, and ductile mechanical performance $[16,17]$. The optical properties of polymers found wide applications in electronic and optical devices such as solar cells, fuel cells, medical technological, and solid state batteries, etc. [18]. Their optical linear absorption coefficient is described by the wellknown Beer-Lambert relation

$\alpha=2.303 \frac{A}{t}$,

where $A$ is defined as $\log \left(I_{0} / I_{T}\right), I_{0}$ and $I_{T}$ are the intensities of the incident and transmitted beams, respectively, and $t$ is the sample thickness [19]. The optical properties of solid thin materials are characterized by the complex dielectric function (real and imaginary), extinction coefficient $(k)$, refractive index $(n)$, and the incidence reflectivity [20]

$R=(n-1)^{2}+k^{2} /(n+1)^{2}+k^{2}$,

so that [21]

$n=\left(1+R_{0}^{1 / 2}\right) /\left(1-R_{0}^{1 / 2}\right)$.

The indirect and direct allowed optical transitions can be evaluated by an appropriate straight line in the strong absorption spectral region by the Tauc relation

$\alpha h \nu=B_{0}\left(h \nu-E_{g}^{\mathrm{opt}}\right)^{r}$

where $E_{g}$ and $h \nu$ are the optical band gap and photon energy, respectively. It could be within values 2,3 , $1 / 2$, or $3 / 2$ for transitions chosen as indirect allowed, indirect prohibited, direct allowed, and direct prohibited, respectively [22]. The calculation of values of the optical energy band gap comprises the scheming of $(\alpha h \nu)^{1 / r}$ with $h \nu[23]$.

The extinction coefficient $(k)$ is determined through [24]

$K=\alpha \lambda / 4 \pi$.

The real $\left(\varepsilon_{r}\right)$ and imaginary $\left(\varepsilon_{i}\right)$ parts of the dielectric constant are given by the following relations [21]:

$\varepsilon_{r}=n^{2}-\kappa^{2}$,

$\varepsilon_{i}=2 n \kappa$. 


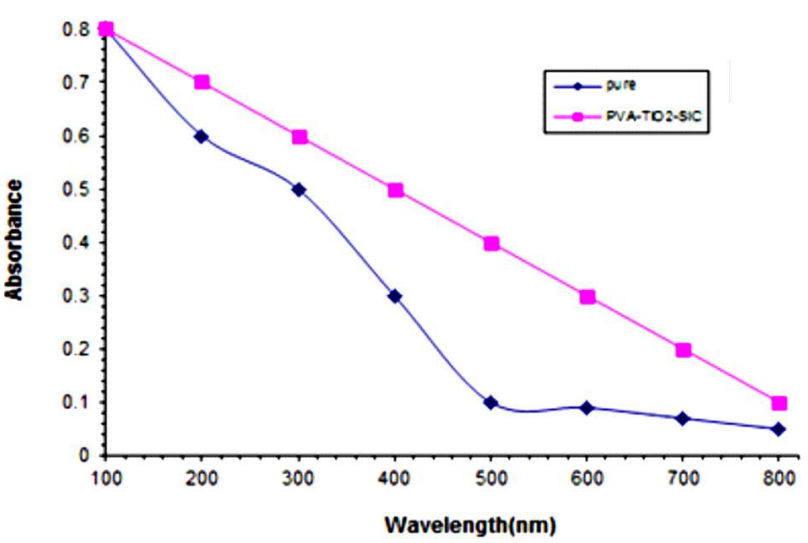

Fig. 1. Variation of the absorbance for $\left(\mathrm{PVA}-\mathrm{TiO}_{2}-\mathrm{SiC}\right)$ nanocomposites with the wavelength

The optical conductivity $\left(\sigma_{\text {opt }}\right)$ is the electric conductivity causing the movement of charge carriers owing to the intermittent electric field of incident electromagnetic waves [25]:

$\sigma_{\mathrm{opt}}=\alpha n c / 4 \pi$

\section{Results and Discussion}

Figures 1 and 2 show the dependences of the absorbance for $\left(\mathrm{PVA}-\mathrm{TiO}_{2}-\mathrm{SiC}\right)$ and $(\mathrm{PVA}-\mathrm{MgO}-\mathrm{SiC})$ nanocomposites on the wavelength of the incident light which are calculated, by using the theoretical programs. The figures show the increase of the absorption by the samples of nanocomposites in the UV region with the concentration of $\mathrm{SiC}$ nanoparticles, which is due to the excitations of donor level electrons to the conduction band at these energies. The absorption increases also with the concentrations of additives, which is related to increase of the number of charge carriers [26-34].

Figures 3 and 4 show that the theoretical variation of the transmittance for $\left(\mathrm{PVA}-\mathrm{TiO}_{2}-\mathrm{SiC}\right)$ and (PVA$\mathrm{MgO}-\mathrm{SiC}$ ) nanocomposites with the wavelength of the incident light. As shown in figures, the transmittance decreases with the increase of the concentrations of $\mathrm{SiC}$ nanoparticles due to the agglomeration of nanoparticles with increasing concentration and the increase of the number of charge carriers $[35,36]$.

The absorption coefficient of nanocomposites is calculated, by using relation (1). Figures 5 and 6 show the theoretical variation of the absorption coefficient for ( $\left.\mathrm{PVA}-\mathrm{TiO}_{2}-\mathrm{SiC}\right)$ and $(\mathrm{PVA}-\mathrm{MgO}-\mathrm{SiC})$ nanocomposites as a function of the photon energy

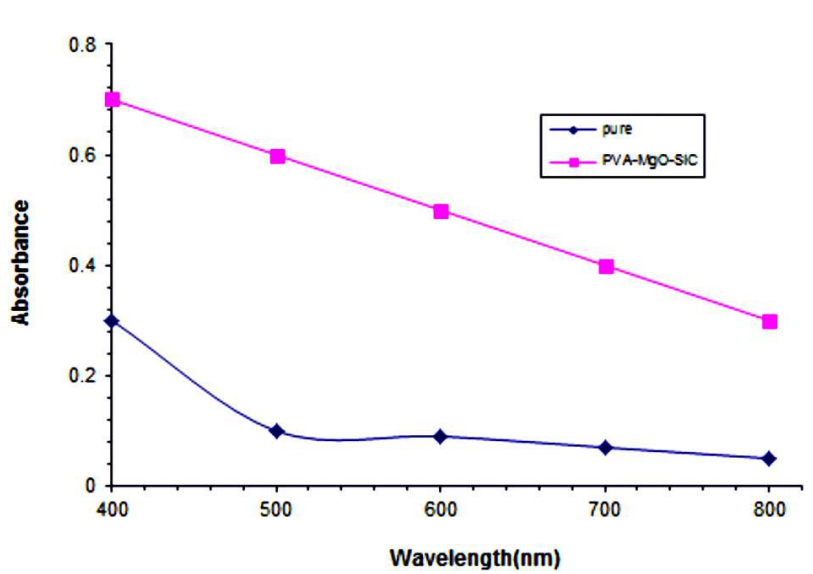

Fig. 2. Variation of the absorbance for (PVA-MgO-SiC) nanocomposites with the wavelength

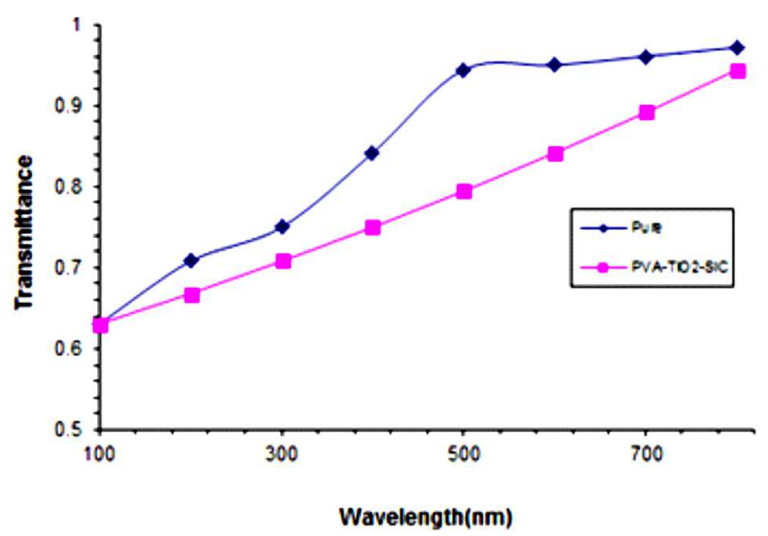

Fig. 3. Variation of the transmittance for $\left(\mathrm{PVA}-\mathrm{TiO}_{2}-\mathrm{SiC}\right)$ nanocomposites with the wavelength

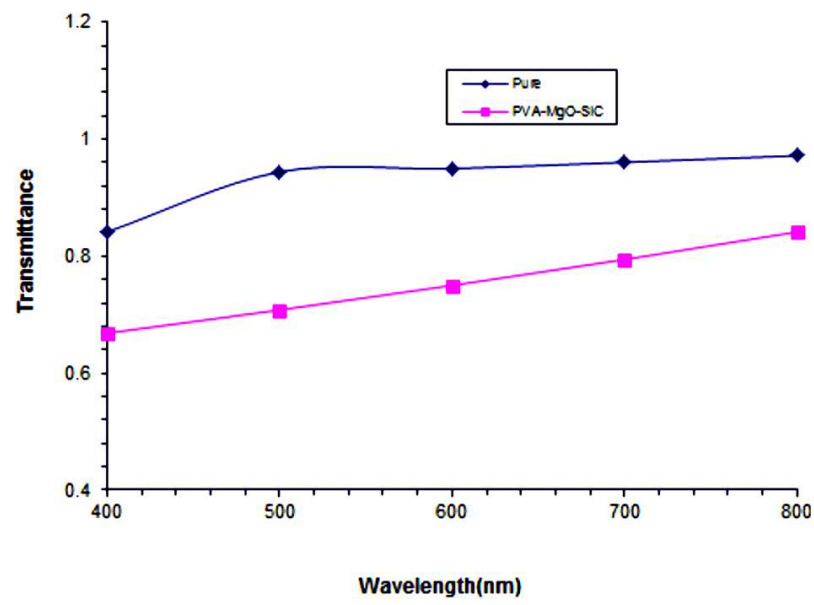

Fig. 4. Variation of the transmittance for (PVA-MgO-SiC) nanocomposites with the wavelength 


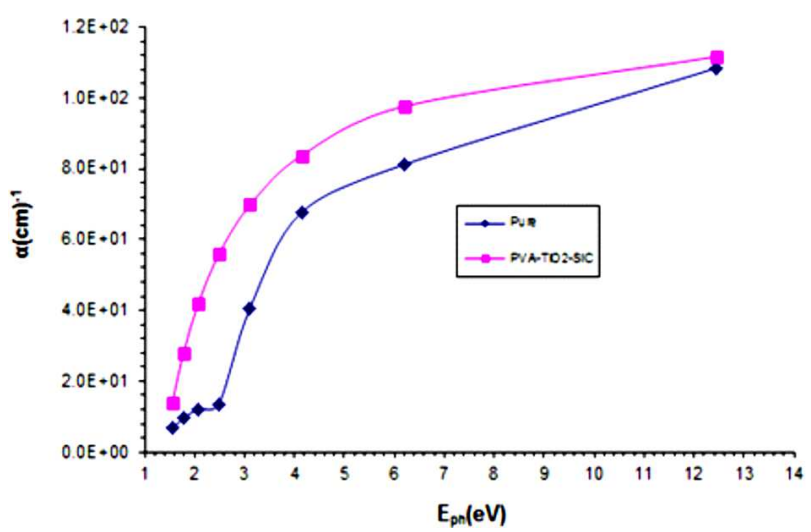

Fig. 5. Variation of the absorption coefficient $(\alpha)$ for (PVA$\mathrm{TiO}_{2}-\mathrm{SiC}$ ) nanocomposites with the photon energy

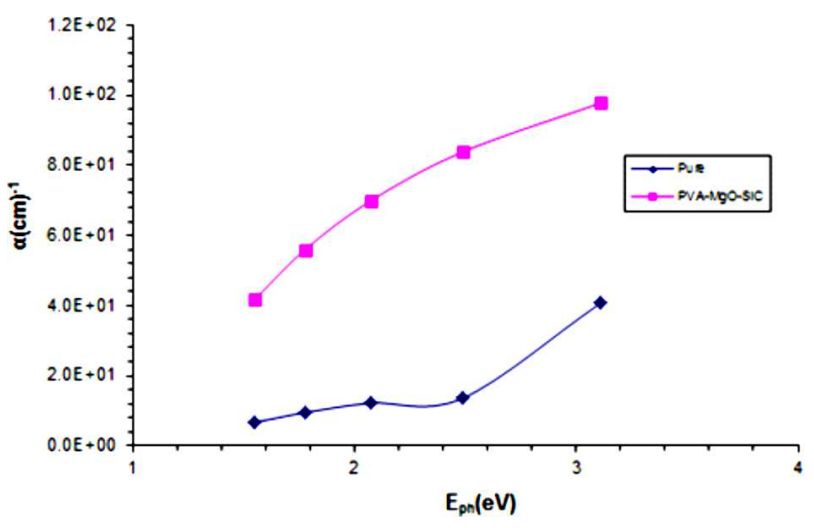

Fig. 6. Variation of the absorption coefficient $(\alpha)$ for (PVA$\mathrm{MgO}-\mathrm{SiC})$ nanocomposites with the photon energy

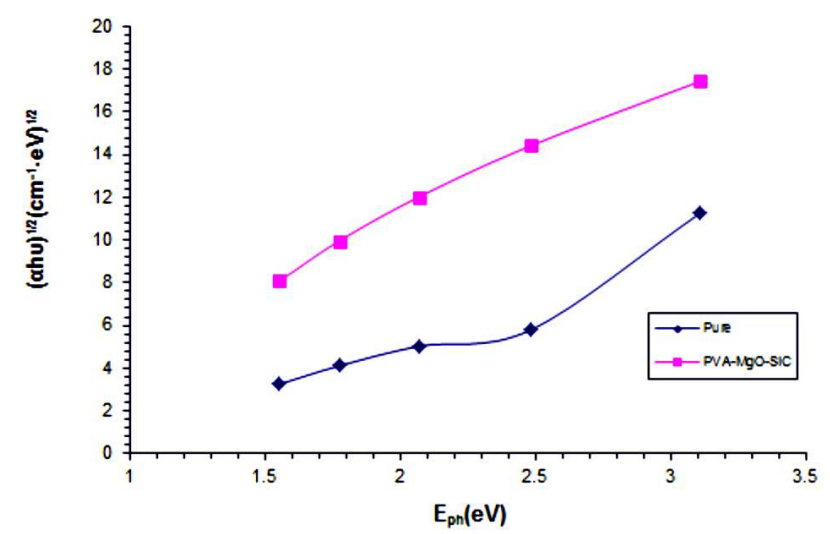

Fig. 7. Variation of $(\alpha h v)^{1 / 2}$ for $\left(\mathrm{PVA}-\mathrm{TiO}_{2}-\mathrm{SiC}\right.$ nanocomposite with the photon energy

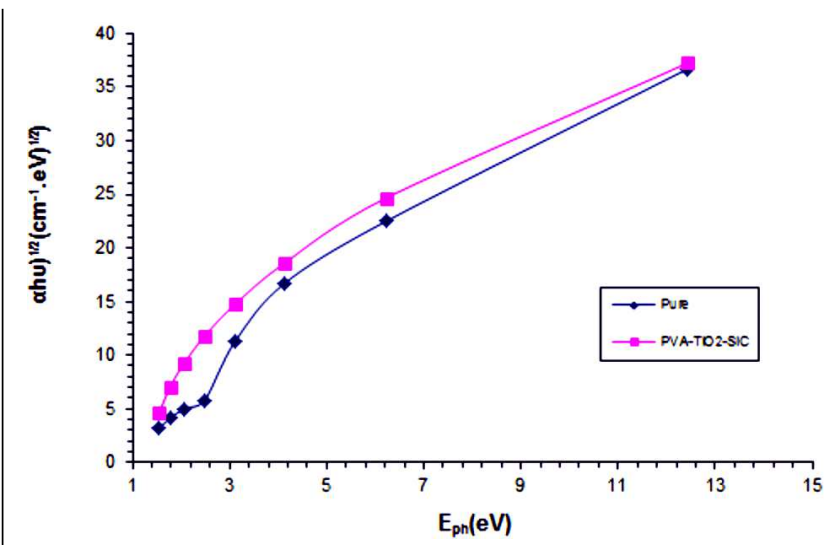

Fig. 8. Variation of $(\alpha h v)^{1 / 2}$ for (PVA-MgO-SiC) nanocomposite with the photon energy

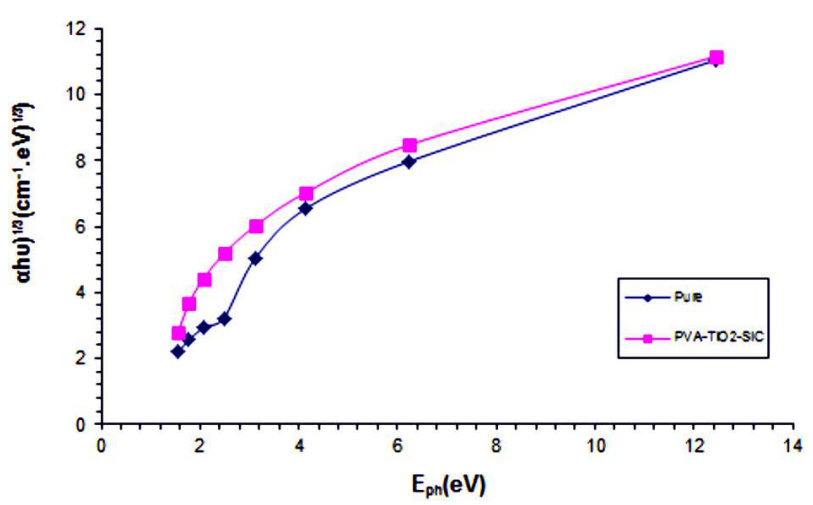

Fig. 9. Variation of $(\alpha h v)^{1 / 3}$ for $\left(\mathrm{PVA}-\mathrm{TiO}_{2}-\mathrm{SiC}\right)$ nanocomposite with the photon energy

of the incident light. As shown in the figures, the absorption coefficient of two samples for nanocomposites is high at high energies. This means that the electron transition from the valence band to the conduction band has high probability, if the energy of the incident photon is greater than the energy band gap. When the values of the absorption coefficient of material are high $\left(\alpha>10^{4} \mathrm{~cm}^{-1}\right)$, the direct transition of the electron is expected. While, when the values of the absorption coefficient of material are low $\left(\alpha<10^{4} \mathrm{~cm}^{-1}\right)$, the indirect transition of the electron is possible. The absorption coefficient of nanocomposites increases with the concentration of nanoparticles; this is attributed to increasing the number of charge carriers [37-47].

The energy band gap of nanocomposites is determined experimentally by using relation (4). The theoretical energy gaps for allowed indirect transitions of $\left(\mathrm{PVA}-\mathrm{TiO}_{2}-\mathrm{SiC}\right)$ and $(\mathrm{PVA}-\mathrm{MgO}-\mathrm{SiC})$ nanocom- 


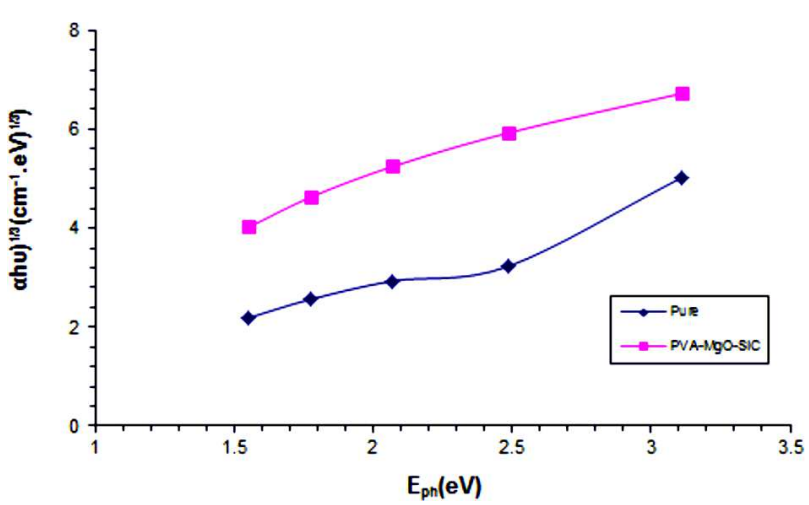

Fig. 10. Variation of $(\alpha h v)^{1 / 3}$ for $(\mathrm{PVA}-\mathrm{MgO}-\mathrm{SiC})$ nanocomposite with the photon energy

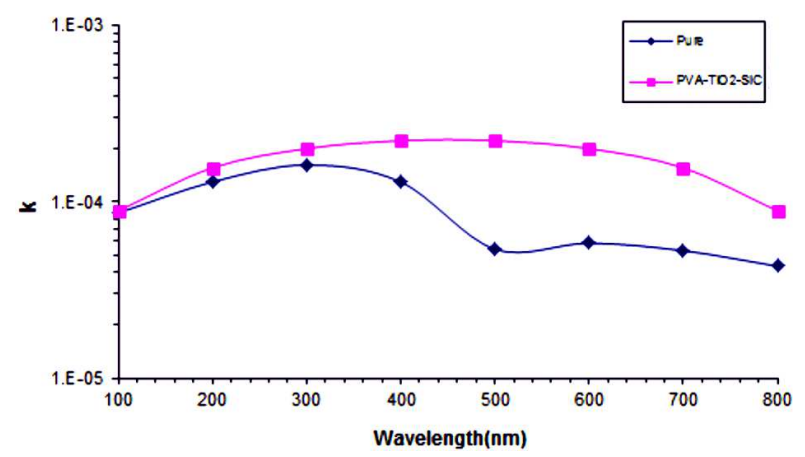

Fig. 11. Variation of the extinction coefficient for (PVA$\mathrm{TiO}_{2}-\mathrm{SiC}$ ) nanocomposite with the wavelength

posites are shown in Figs. 7 and 8. The theoretical energy gaps for forbidden indirect transitions of (PVA$\left.\mathrm{TiO}_{2}-\mathrm{SiC}\right)$ and (PVA-MgO-SiC) nanocomposites are shown in Figs. 9 and 10). As is shown in the figures, the energy gaps for allowed and forbidden indirect transitions of nanocomposites are decreased with the increase of the concentration of $\mathrm{SiC}$ nanoparticles, this behavior is due to the creation of levels in the energy gap; the transition of an electron in this case is executed in two stages that involve the transition from the valence band to a local level in the energy gap and then to the conduction band as a result of increasing the concentration of $\mathrm{SiC}$ nanoparticles; the electronic conduction depends on the concentration of nanoparticles [48, 49].

The extinction coefficient is calculated, by using relation (5). Figures 11 and 12 show the variation of the calculated extinction coefficient for $\left(\mathrm{PVA}-\mathrm{TiO}_{2}-\mathrm{SiC}\right)$ and $(\mathrm{PVA}-\mathrm{MgO}-\mathrm{SiC})$ nanocomposites as a function of the wavelength. The figures show that the extinction coefficient of nanocomposites increases with the

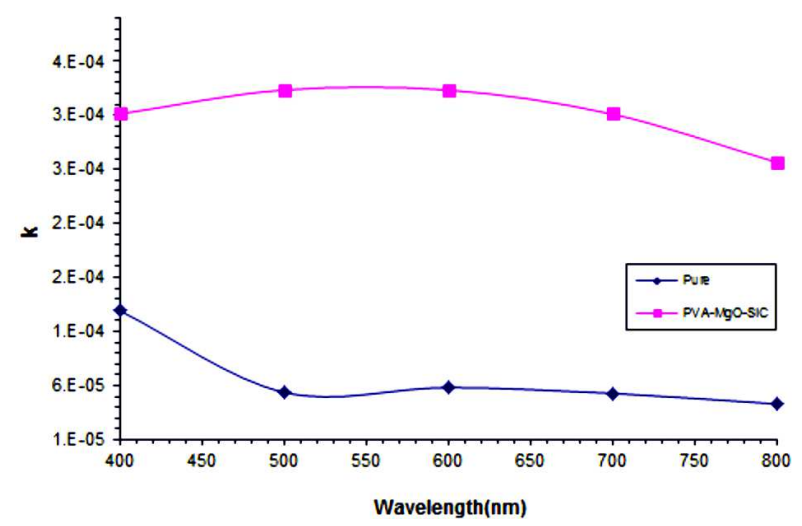

Fig. 12. Variation of the extinction coefficient for (PVA$\mathrm{MgO}-\mathrm{SiC}$ ) nanocomposite with the wavelength

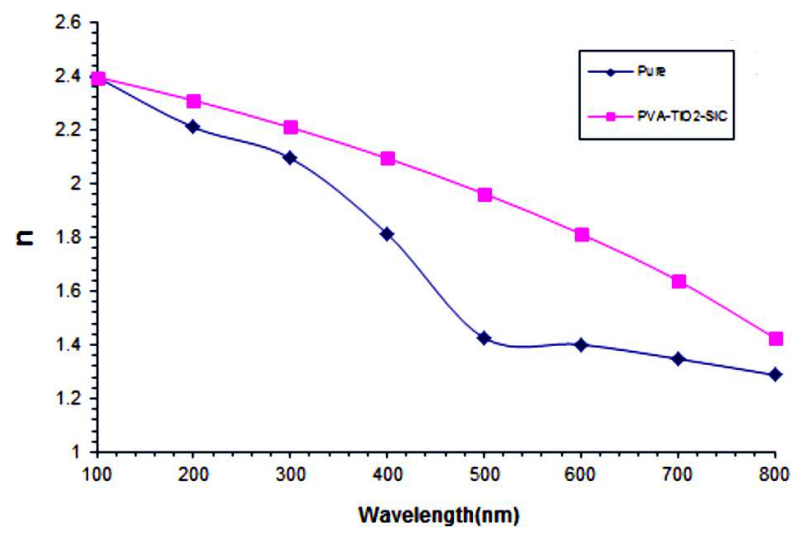

Fig. 13. Variation of the refractive index for $\left(\mathrm{PVA}-\mathrm{TiO}_{2}-\right.$ $\mathrm{SiC})$ nanocomposite with the wavelength

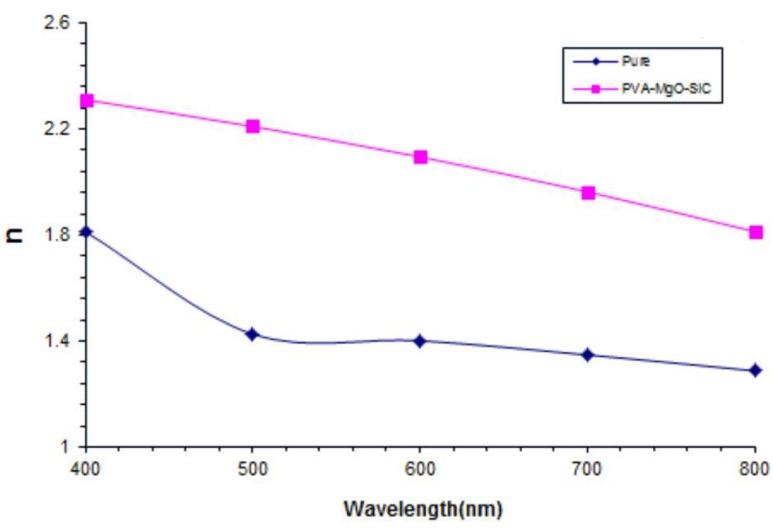

Fig. 14. Variation of the refractive index for (PVA-MgO-SiC) nanocomposite with the wavelength

concentration of $\mathrm{SiC}$ nanoparticles, this is due to the increase in the optical absorption and the dispersion of photons in the nanocomposites [50]. 


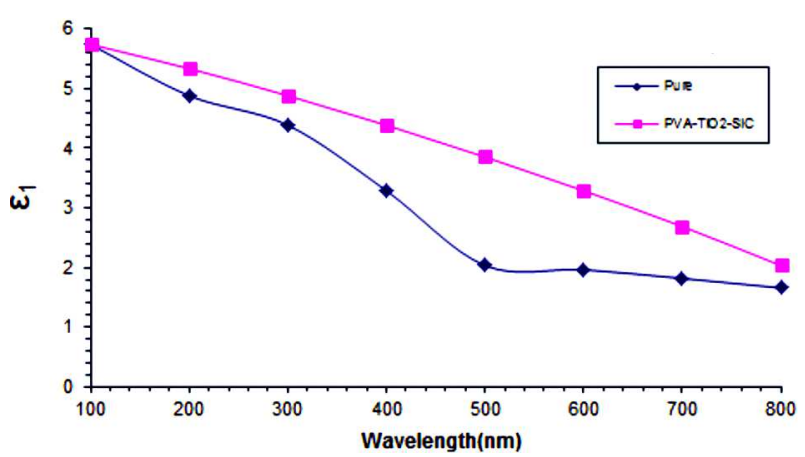

Fig. 15. Variation of the real part of the dielectric constant for $\left(\mathrm{PVA}-\mathrm{TiO}_{2}-\mathrm{SiC}\right)$ nanocomposite with the wavelength

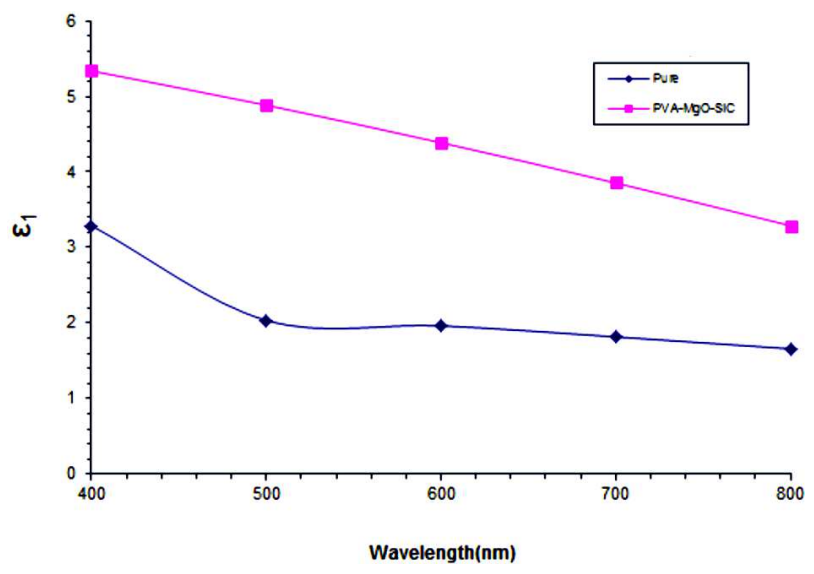

Fig. 16. Variation of the real part of the dielectric constant for (PVA-MgO-SiC) nanocomposite with the wavelength

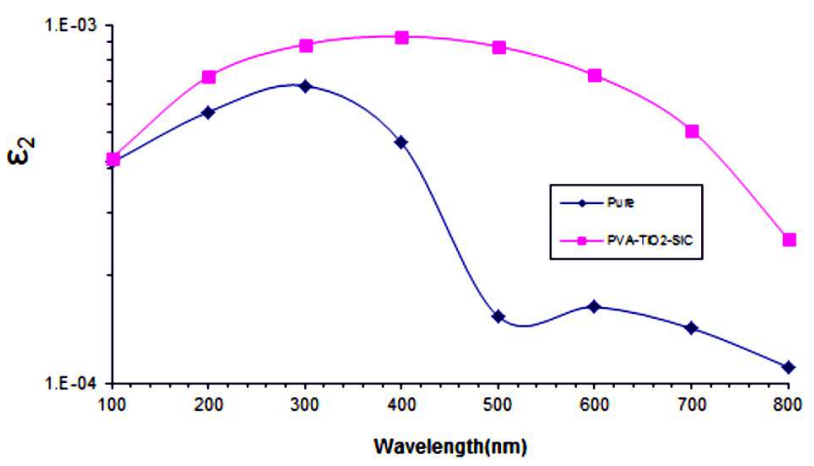

Fig. 17. Variation of the imaginary part of the dielectric constant for $\left(\mathrm{PVA}-\mathrm{TiO}_{2}-\mathrm{SiC}\right)$ nanocomposite with the wavelength

The calculated refractive indices of $\left(\mathrm{PVA}-\mathrm{TiO}_{2}-\right.$ $\mathrm{SiC}$ ) and (PVA-MgO-SiC) nanocomposites as functions of the wavelength are shown in Figs. 13 and 14. As shown in the figures, the refractive index of nanocomposites increases with the concentration of

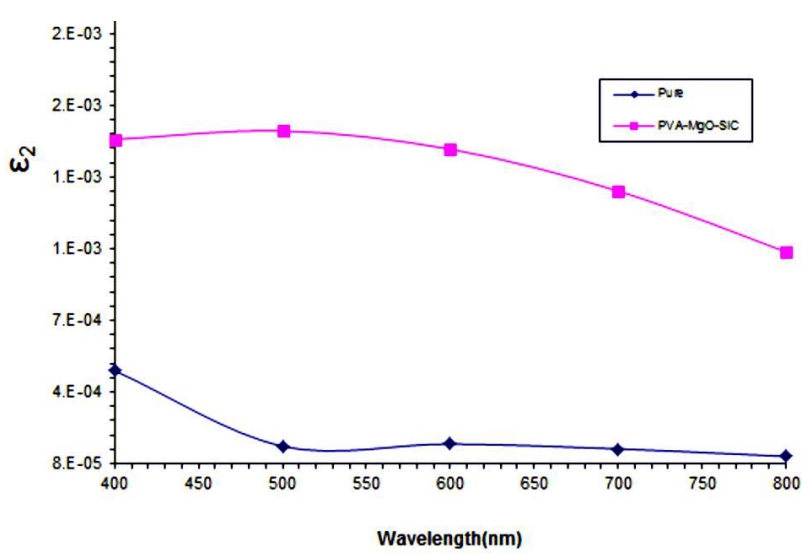

Fig. 18. Variation of the imaginary part of the dielectric constant for (PVA-MgO-SiC) nanocomposite with the wavelength

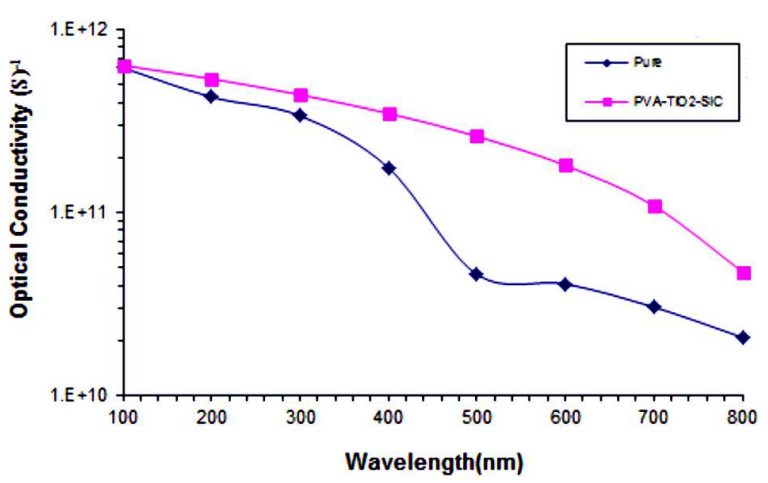

Fig. 19. Variation of the optical conductivity for $\left(\mathrm{PVA}-\mathrm{TiO}_{2}-\right.$ $\mathrm{SiC})$ nanocomposite with the wavelength

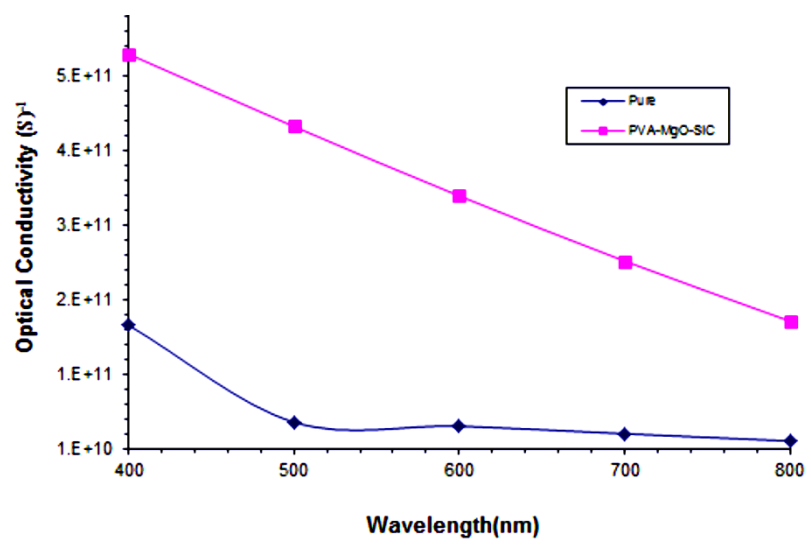

Fig. 20. Variation of the optical conductivity for (PVA-MgO$\mathrm{SiC})$ nanocomposite with the wavelength

$\mathrm{SiC}$ nanoparticles; it decreases with the increase of the wavelength. This behavior is attributed to the increase of the density of nanocomposites.

ISSN 2071-0194. Ukr. J. Phys. 2020. Vol. 65, No. 6 
The real and imaginary parts of the dielectric constant are calculated, by using relations (6) and (7) respectively. Figures 15 and 16 show the theoretical variation of the real dielectric constant with the wavelength for (PVA- $\mathrm{TiO}_{2}-\mathrm{SiC}$ ) and (PVA-MgO$\mathrm{SiC}$ ) nanocomposites. A loss peak attributed to the interfacial polarization can be seen. These relaxation peaks move toward the lower side, as the concentration of $\mathrm{SiC}$ in the composites increases.

The effect of $\mathrm{SiC}$ nanoparticles on the theoretical imaginary part of the dielectric constant is shown in Figs. 17 and 18 for (PVA-TiO ${ }_{2}-\mathrm{SiC}$ ) and (PVA$\mathrm{MgO}-\mathrm{SiC}$ ) nanocomposites. The figures show that the imaginary parts of the dielectric constants of $\left(\mathrm{PVA}-\mathrm{TiO}_{2}\right)$ and $(\mathrm{PVA}-\mathrm{MgO})$ nanocomposites increase with the concentration of $\mathrm{SiC}$ nanoparticles, this behavior is attributed to the increase of the electric polarization due to the contribution of the concentration of nanoparticles in the sample [51, 52].

Figures 19 and 20 show the calculated variation of the optical conductivity with the wavelength for $\left(\mathrm{PVA}-\mathrm{TiO}_{2}-\mathrm{SiC}\right)$ and (PVA-MgO-SiC) nanocomposites. The optical conductivity of nanocomposites increases with the concentration of $\mathrm{SiC}$ nanoparticles, this behavior is related to the creation of localized levels in the energy gap; the increase of the concentration of $\mathrm{SiC}$ nanoparticles increases the density of localized states in the band structure. Hence, the increase of the absorption coefficient consequently increases the optical conductivity [53-58] of $\left(\mathrm{PVA}-\mathrm{TiO}_{2}-\mathrm{SiC}\right)$ and (PVA-MgO-SiC) nanocomposites.

\section{Conclusions}

The results showed that the $\left(\mathrm{PVA}-\mathrm{TiO}_{2}-\mathrm{SiC}\right)$ and (PVA-MgO-SiC) nanocomposites have higher absorbance in the UV region. The absorbance, absorption coefficient, extinction coefficient, refractive index, imaginary and real dielectric constants, and optical conductivity of $\left(\mathrm{PVA}-\mathrm{TiO}_{2}\right)$ and $(\mathrm{PVA}-\mathrm{MgO})$ nanocomposites increase with the concentration of $\mathrm{SiC}$ nanoparticles. The $\left(\mathrm{PVA}-\mathrm{TiO}_{2}-\mathrm{SiC}\right)$ and $(\mathrm{PVA}-$ $\mathrm{MgO}-\mathrm{SiC}$ ) nanocomposites have indirect energy gaps $1 \mathrm{eV}<E_{g}<2.2 \mathrm{eV}$, which makes them useful for various applications in optoelectronics, photovoltaics, lasers, solar cells, sensors, photocatalytic devices, light filters, UV detectors, etc. with low cost, easy fabrication, and flexibility as compared with other devices.
1. G. Valli, A. Jayalakshmi. Erythrina ariegate leaves extract assisted synthesis of titanium dioxide nanoparticles in an ecofriendly approach. Europ. J. Biomedical and Pharmaceutical Sci. 2, 490 (2015).

2. A. Kumar, K. Kaur, S. Sharma. Synthesis, characterization and antibacterial potential of silver nanoparticles by Morusnigra leaf extract. Indian J. Pharm. Biol. Res. 1, 4 (2013).

3. D.R. Paul, L.M. Robeson. Polymer nanotechnology: Nanocomposites. Polymer 49, 15 (2008).

4. S.K. Sharma, J. Prakash, K. Sudarshan, D. Sen, S. Mazumder, P.K. Pujari. Structure at interphase of poly (vinyl alcohol)-SiC nanofiber composite and its impact on mechanical properties: Positron annihilation and smallangle X-ray scattering studies. Macromolecules 48, 16 (2015).

5. S. Ningaraju, A.G. Prakash, H.B. Ravikumar. Studies on free volume controlled electrical properties of $\mathrm{PVA} / \mathrm{NiO}$ and PVA $/ \mathrm{TiO}_{2}$ polymer nanocomposites. Solid State Ionics 320, 1 (2018).

6. Q. Xiang, J. Yu, M. Jaroniec. Graphene-based semiconductor photocatalysts. Chem. Soc. Rev. 41, 2 (2012).

7. K. Hermann, M. Witko. Theory of physical and chemical behavior of transition metal oxides: Vanadium and molybdenum oxides. In: Oxide Surfaces (Elsevier, 2001), Ch. 4, p. 136.

8. P.H.C. Camargo, K.G. Satyanarayana, F. Wypych. Nanocomposites: Synthesis, structure, properties and new application opportunities. Mater. Res. 12, 1 (2009).

9. S.G. Rathod, R.F. Bhajantri, V. Ravindrachary, T. Sheela, P.K. Pujari, J. Naik, B. Poojary. Pressure sensitive dielectric properties of $\mathrm{TiO}_{2}$ doped PVA/CN-Li nanocomposite. J. Polymer Res. 22, 2 (2015).

10. S.B. Aziz, M.A. Rasheed, S.R. Saeed, O.G. Abdullah. Synthesis and characterization of CdS nanoparticles grown in a polymer solution using in-situ chemical reduction technique. Int. J. Electrochem. Sci. 12, 3236 (2017).

11. M.B. Omar, A. Matoussi. Dielectric and conductivity investigations of rutile titanium dioxide single crystals. In: Electrical Insulation and Dielectric Phenomena (IEEE, 2012), p. 261.

12. M. Hdidar, S. Chouikhi, A. Fattoum, M. Arous, A. Kallel. Influence of $\mathrm{TiO}_{2}$ rutile doping on the thermal and dielectric properties of nanocomposite films based on PVA. J. Alloys and Compounds 750, 1 (2018).

13. Z.X. Tang, B.F. Lv. MgO nanoparticles as antibacterial agent: Preparation and activity. Brazilian J. Chem. Engineering 31, 3 (2014).

14. F.L. Rashid, A. Hadi, N.H. Al-Garah, A. Hashim. Novel phase change materials, $\mathrm{MgO}$ nanoparticles, and water based nanofluids for thermal energy storage and biomedical applications. Intern. J. Pharmac. Phytopharmac. Res. 8, 1 (2018).

15. R. Peverati, D.G. Truhlar. M11-L: A local density functional that provides improved accuracy for electronic struc- 
ture calculations in chemistry and physics. J. Phys. Chem Lett. 3, 1 (2011).

16. X. Zhao, Y. Long, T. Yang, J. Li, H. Zhu. Simultaneous high sensitivity sensing of temperature and humidity with graphene woven fabrics. ACS Appl. Mater. \& Interfaces $\mathbf{9}$, 35 (2017).

17. T. Yang, D. Xie, Z. Li, H. Zhu. Recent advances in wearable tactile sensors: Materials, sensing mechanisms, and device performance. Mater. Sci. Engin.: Rep. 115, 1 (2017).

18. Z.J. Zhong. Optical properties and spectroscopy of nanomaterials (World Scientific, 2009).

19. S. Ilican, M. Caglar, Y. Caglar. The effect of deposition parameters on the physical properties of $\mathrm{Cd}_{x} \mathrm{Zn}_{1-x} \mathrm{~S}$ films deposited by spray pyrolysis method. J. Optoelectronics and Advanced Materials 9, 5 (2007).

20. T.K. Hamad, R.M. Yusop, B. Abdullah, E. Yousif. Laser induced modification of the optical properties of nano- $\mathrm{ZnO}$ doped PVC films. Inter. J. Polymer Sci. Article ID 787595 (2014).

21. A.A. Nathan, A. Onoja, A. Amah. Influence of PVA, PVP on crystal and optical properties of europium doped strontium aluminate nanoparticles. Amer. J. Eng. Res. 4, 4 (2015)

22. S. Suresh. Investigation of the optical and dielectric properties of the urea L-malic acid NLO single crystal. Amer. Chem. Sci. J. 3, 3 (2013).

23. K.C. Lalithambika, K. Shanthakumari, S. Sriram. Optical properties of Cdo thin films deposited by chemical bath method. Int. J. Chemtech Res. 6, 5 (2014).

24. F.E. Ghodsi, H. Absalan. Comparative study of $\mathrm{ZnO}$ thin films prepared by different sol-gel route. Acta Phys. Polon. - Ser. A General Phys. 118, 4 (2010).

25. M.A. Gaffa, A.A. El-Fadl, S.B. Anooz. Influence of strontium doping on the indirect band gap and optical constants of ammonium zinc chloride crystals. Phys. B: Condensed Matter. 327 (1), 43 (2003).

26. A. Hashim, Z.S. Hamad. Fabrication and characterization of polymer blend doped with metal carbide nanoparticles for Humidity sensors. J. Nanostruct. 9, 2 (2019).

27. B.H. Rabee, A. Hashim. Synthesis and characterization of carbon nanotubes -polystyrene composites. Europ. J. Sci. Res. 60, 2 (2011).

28. A. Hashim, M.A. Habeeb, A. Khalaf, A. Hadi. Fabrication of (PVA-PAA) blend-extracts of plants bio-composites and studying their structural. Electrical and optical properties for Humidity sensors. Appl. Sensor Lett. 15, 7 (2017),

29. S. Hadi, A. Hashim, A. Jewad. Optical properties of (PVALiF) composites. Australian J. Basic and Appl. Sci. 15, 9 (2011).

30. Q.M. Jebur, A. Hashim, M.A. Habeeb. Structural, electrical and optical properties for (Polyvinyl AlcoholPolyethylene Oxide-Magnesium Oxide) nanocomposites for optoelectronics applications. Transactions on Electrical and Electronic Materials 20, 1 (2019).

31. F.A. Jasim, A. Hashim, Az.G. Hadi, F. Lafta, S.R. Salman, H. Ahmed. Preparation of (pomegranate peel-polystyrene) composites and study their optical properties. Res. J. Appl. Sci. 8, 9 (2013).

32. F.A. Jasim, F. Lafta, A. Hashim, M. Ali, A.G. Hadi. Characterization of palm fronds-polystyrene composites. J. Engineering and Appl. Sci. 8, 5 (2013). .

33. I.R. Agool, F.S. Mohammed, A. Hashim. The effect of magnesium oxide nanoparticles on the optical and dielectric properties of (PVA-PAA-PVP) blend. Advances in Environmental Biology 9, 11 (2015).

34. F.L. Rashid, A. Hashim, M.A. Habeeb, S.R. Salman, H. Ahmed. Preparation of PS-PMMA copolymer and study of the effect of sodium fluoride on its optical properties. J. Engineering and Appl. Sci. 8, 5 (2013).

35. N.G. Imam, M.B. Mohamed. Environmentally friendly $\mathrm{Zn}_{0} \cdot{ }^{75} \mathrm{Cd}_{0}$. 25S/PVA heterosystemnanocomposite: UVstimulated emission and absorption spectra. J. Molecular Structure 1105, 80 (2016).

36. A. Hashim, A. Hadi. Synthesis and characterization of $\left(\mathrm{MgO}-\mathrm{Y}_{2} \mathrm{O}_{3}-\mathrm{CuO}\right)$ nanocomposites for novel humidity sensor application. Sensor Lett. 15, 10 (2017).

37. G.A.M. Amin, M.H. Abd-El Salam. Optical, dielectric and electrical properties of PVA doped with Sn nanoparticles. Mater. Res. Express 1, 2 (2014).

38. A. Hazim, H.M. Abduljalil, A. Hashim. Analysis of structural and electronic properties of novel ( $\mathrm{PMMA} / \mathrm{Al}_{2} \mathrm{O}_{3}$, $\mathrm{PMMA} / \mathrm{Al}_{2} \mathrm{O}_{3}-\mathrm{Ag}, \quad \mathrm{PMMA} / \mathrm{ZrO}_{2}, \quad \mathrm{PMMA} / \mathrm{ZrO}_{2}-\mathrm{Ag}$, PMMA-Ag) nanocomposites for low cost electronics and optics applications. Transactions on Electrical and Electronic Mater. 21, 48 (2020).

39. H. Ahmed, A. Hashim. Fabrication of novel (PVA/NiO/ $\mathrm{SiC})$ nanocomposites, structural, electronic and optical properties for Humidity sensors. Intern. J. Sci. \& Technology Res. 8, 11 (2019).

40. A. Hashim, A. Jassim. Novel of biodegradable polymersinorganic nanoparticles: Structural, optical and electrical properties as Humidity sensors and gamma radiation shielding for biological applications. J. Bionanoscience 12, 2 (2018)

41. A. Hashim, M.A. Habeeb, A. Hadi. Synthesis of novel polyvinyl alcohol-starch-copper oxide nanocomposites for Humidity sensors applications with different temperatures. Sensor Lett. 15, 9 (2017).

42. A. Hadi, A. Hashim. Development of a new humidity sensor based on (carboxymethyl cellulose-starch) blend with copper oxide nanoparticles. Ukr. J. Phys. 62, 12 (2017).

43. A. Hashim, A. Jassim. Novel of (PVA-ST-PbO $\left.{ }_{2}\right)$ bio nanocomposites: Preparation and properties for Humidity sensors and radiation shielding applications. Sensor Lett. 15, 12 (2017).

44. H. Ahmed, H.M. Abduljalil, A. Hashim. Structural, optical and electronic properties of novel (PVA-MgO)/SiC nanocomposites films for Humidity sensors. Transactions on Electrical and Electronic Mater. 20218 (2019).

45. H. Ahmed, H.M. Abduljalil, A. Hashim. Analysis of structural, optical and electronic properties of poly-

ISSN 2071-0194. Ukr. J. Phys. 2020. Vol. 65, No. 6 
meric nanocomposites/silicon carbide for Humidity sensors. Transactions on Electrical and Electronic Mater. 20, 206 (2019).

46. A. Hashim, Y. Al-Khafaji, A. Hadi. Synthesis and characterization of flexible resistive Humidity sensors based on PVA/PEO/CuO Nanocomposites. Transactions on Electrical and Electronic Mater. (2019).

47. A. Hashim, N. Hamid. Fabrication and properties of biopolymer-ceramics nanocomposites as UV-shielding for bionanoscience application. J. Bionanoscience 12, 6 (2018).

48. S. Salman, N. Bakr, M.H. Mahmood. Preparation and study of some optical properties of (PVA-Ni( $\left.\left.\mathrm{CH}_{3} \mathrm{COO}\right)_{2}\right)$ composites. Int. J. Curr. Res. 6, 11 (2014).

49. A.M. Abdelghany, E.M. Abdelrazek, D.S. Rashad. Impact of in situ preparation of CdS filled PVP nano-composite. Spectrochimica Acta Part A: Molecular and Biomolecular Spectroscopy 130, 302 (2014).

50. D.E. Hegazy, M. Eid, M. Madani. Effect of Ni nano particles on thermal, optical and electrical behaviour of irradiated PVA/AAc films. Arab J. Nucl. Sci. Appl. 47, 1 (2014).

51. A. Hashim, Q. Hadi. Novel of (Niobium Carbide/Polymer Blend) nanocomposites: Fabrication and characterization for pressure sensor. Sensor Lett. 15, 11 (2017),

52. A. Hashim, A. Hadi. A novel piezoelectric materials prepared from (Carboxymethyl Cellulose-Starch) blend-metal oxide nanocomposites. Sensor Lett. 15, 12 (2017).

53. Z.H. Esfahani, M. Ghanipour, D. Dorranian. Effect of dye concentration on the optical properties of red-BS dyedoped PVA film. J. Theor. Appl. Phys. 8, 4 (2014).

54. A. Hashim, A. Hadi. Novel lead oxide polymer nanocomposites for nuclear radiation shielding applications. Ukr. J. Phys. 62, 11 (2017).

55. A. Hashim, Q. Hadi. Structural, electrical and optical properties of (biopolymer blend/titanium carbide) nanocomposites for low cost humidity sensors. J. Mater. Sci.: Mater. Electron. 29, 11598 (2018).

56. A. Hashim, Q. Hadi. Synthesis of novel (Polymer BlendCeramics) nanocomposites: Structural, optical and elec- trical properties for Humidity sensors. J. Inorganic and Organometallic Polymers and Mater. 28, 4 (2018).

57. A. Hashim, I.R. Agool, K.J. Kadhim. Novel of (Polymer Blend- $\mathrm{Fe}_{3} \mathrm{O}_{4}$ ) magnetic nanocomposites: Preparation and characterization for thermal energy storage and release, gamma ray shielding, antibacterial activity and Humidity sensors applications. J. Mater. Sci.: Mater. Electronics 29, 12 (2018).

58. A. Hashim, K.H.H. Al-Attiyah, S.F. Obaid. Fabrication of novel (biopolymer blend-lead oxide nanoparticles) nanocomposites: structural and optical properties for lowcost nuclear radiation shielding. Ukr. J. Phys. 64, No. 2, 157 (2019).

Received 24.08.19

Х. Ахмед, А. Хашім, Х.М. Абдулджаліл

\section{ВИЗНАЧЕННЯ ОПТИЧНИХ}

ПАРАМЕТРІВ ПЛІВОК PVA $/ \mathrm{TiO}_{2} / \mathrm{SiC}$

I PVA/MgO/SiC HАНОКОМПОЗИТІВ

ДЛЯ ОПТОЕЛЕКТРОНІКИ І УФ-ДЕТЕКТОРІВ

$\mathrm{P}$ е 3 ю м е

Розраховано оптичні властивості нанокомпозитів полівініловий спирт (PVA)-окис титану $\left(\mathrm{TiO}_{2}\right)$-карбід кремнію ( $\mathrm{SiC})$ та (PVA)-окис магнію $(\mathrm{MgO})-(\mathrm{SiC})$ з використанням програм Gaussian 09 і Gaussian view 5.0.8 на основі теорії функціонала щільності на рівні B3LYP з базисом 631 G. Результати показують, що спектральна поглинальна здатність, коефіцієнти поглинання і екстинції, показник заломлення, уявна і дійсна діелектричні сталі та оптична провідність ( $\left.\mathrm{PVA}-\mathrm{TiO}_{2}-\mathrm{SiC}\right)$ і (PVA-MgO-SiC) зростають зі збільшенням концентрації наночастинок $\mathrm{SiC}$. Обидва нанокомпозита проявляють високу спектральну поглинальну здатність в ультрафіолетовій (УФ) області і мають непрямі енергетичні щілини $1 \mathrm{eB}<E_{g}<2,2 \mathrm{eB}$. Ці властивості, дешевизна, простота виготовлення і використання роблять їх корисними для застосувань в оптоелектроніці, фотокаталізі, лазерах, фотоелектричних і сонячних батареях, сенсоpax, фільтрах світла, УФ-детекторах і т.п. 